\title{
EFEKTIFITAS TERAPI MUROTTAL AL-QUR'AN TERHADAP TINGKAT KECEMASAN MAHASISWA SEBELUM UJIAN SKILL LABORATORY
}

\author{
Efriza Resti Rusdi ${ }^{1}$, Yesi Hasneli ${ }^{2}$, Sri Wahyuni ${ }^{3}$ \\ ${ }^{1,2,3}$ Fakultas Keperawatan Universitas Riau Jalan Pattimura No 9 Gedung G Pekanbaru Riau \\ Kode Pos 28131 Indonesia \\ Email: efriza.restirusdi@yahoo.com
}

\begin{abstract}
Abstrak
Ujian skill laboratory merupakan evaluasi terhadap kemampuan yang dicapai mahasiswa dalam bidang keterampilan keperawatan yang bertujuan menunjang kompetensi klinik. Evaluasi ini dapat menimbulkan kecemasan, sehingga berdampak terhadap hasil akhir evaluasi. Tujuan penelitian ini untuk mengetahui efektifitas terapi murottal Al-Qur'an terhadap tingkat kecemasan mahasiswa sebelum ujian skill laboratory di Fakultas Keperawatan Universitas Riau. Desain penelitian ini adalah quasy eksperiment dan rancangan penelitian pretest-postest design with control group. Teknik pengambilan sampel menggunakan simple random sampling dengan jumlah sampel sebanyak 68 orang responden. Alat ukur yang digunakan adalah kuesioner S-AI (State Anxiety Inventori) from Y-1. Analisa statistik menggunakan uji dependent $t$-test dan independent $t$-test. Hasil analisa univariat diperoleh mayoritas umur responden 18 tahun sebanyak 37 orang $(54,4 \%)$ dan tingkat kecemasan berat tertinggi pada umur 18 tahun, mayoritas jenis kelamin perempuan sebanyak 66 orang $(97,1 \%)$ dan tingkat kecemasan berat tertinggi pada jenis kelamin perempuan. Rata-rata tingkat kecemasan kelompok eksperimen pre-test adalah 60,35 dan post-test adalah 36,41, sedangkan kelompok kontrol pre-test adalah 54,06 dan post-test adalah 54,56. Hasil analisis statistik menunjukkan terapi murottal Al-Qur'an efektif menurunkan tingkat kecemasan mahasiswa sebelum ujian skill laboratory dengan $p$-value $=0,000<\alpha(0,05)$. Terapi murottal Al-Qur'an dapat direkomendasikan sebagai terapi alternatif bagi mahasiswa dalam mengatasi kecemasan menghadapi ujian skill laboratory.
\end{abstract}

Kata kunci : kecemasan, murottal Al-Qur'an, skill laboratory

\begin{abstract}
Skill laboratory examination is an evaluation of the abilities achived by students in the field of nursing skills aimed at supporting clinical competence. This evaluation can cause anxiety so that it has impact on the final outcome of the evaluation. The purpose of this study to determine the effectiveness of murottal Al-Qur'an therapy on the anxiety level of students before the skill laboratory examination at the University of Riau Nursing Faculty. The design of this research is quasy experiment and pretest-posttest design with control group research design. The sampling technique used simple random sampling with the amount of 68 respondents. The measuring instrument used is the S-AI (State Anxiety Inventory) from the Y-1 questionaire. The analysis used was univariate and bivariate analysis with the dependent $t$-test and independent $t$-test. Univariate analysis was used to determine the frequency distribution of respondent characteristic, the result showed that the majority of respondents were 18 years old as many as 37 people (54.4\%), and the highest severe anxiety level was found at the age of 18 years, most of the respondents were female as much as 66 people (97.1\%) and the highest severe anxiety level was found from the female. The average anxiety level on the intervention group pre-test 60.35 and post-test 36.41, while the control group pre-test 54.06 and post-test 54.56. The statistical results obtained a p-value of $0.000<\alpha(0.05)$, so it can be concluded that murottal AlQur'an therapy was effective against the anxiety level of students before the skill laboratory examination. Murottal therapy could be recommended alternative therapies to overcome skill laboratory test anxiety.
\end{abstract}

Keywords : anxiety, murottal Al-Qur'an, skill laboratory 


\section{PENDAHULUAN}

Kecemasan adalah respon normal sebagai pertanda akan bahaya yang mengancam didalam kehidupan (Hawari, 2011). Menurut Ibrahim (2012) kecemasan berfungsi sebagai mekanisme alarm untuk mempersiapkan seorang individu dalam upaya merespon secara fisik terhadap bahaya, dan peristiwa yang mengancam dan penuh tekanan. Kecemasan dapat mengakibatkan rasa ketidakberdayaan dan ketidaknyamanan terhadap diri sendiri (Kusumawati \& Hartono, 2011).

Ketidakberdayaan dan ketidaknyamanan merupakan respon fisiologi dari kecemasan yang diatur oleh otak melalui saraf autonomik yang dapat menimbulkan respon simpatis, dimana respon simpatis ini berfungsi melindungi diri dari ancaman dengan cara mengeluarkan hormon adrenalin, norepineprin, kortisol, dan menurunkan nitrit oxide yang dapat menyebabkan perubahan respon tubuh seperti jantung, pernafasan, otot menegang, tekanan darah meningkat, sulit berfikir jernih, serta peningkatan metabolisme. Sedangkan respon parasimpatis mengembalikan tubuh keposisi normal setelah ancaman berakhir (Ibrahim, 2012).

\section{Menurut World Health Organization} (2017), gangguan mental yang terjadi pada umumnya adalah gangguan kecemasan dan gangguan depresi, yang diperkirakan sekitar $3,6 \%$ dari populasi global menderita gangguan kecemasan dan 4,4\% menderita gangguan depresi. Jumlah penderita kecemasan dan depresi mengalami peningkatan lebih dari $18 \%$ antara tahun 2005-2015 (WHO, 2017).

Prevalensi di Indonesia terkait gangguan mental emosional yang ditunjukkan dengan gejala-gejala kecemasan dan depresi mengalami kenaikan yakni 1,7\% menjadi $7 \%$ pada usia 15 tahun ke atas dari tahun 20132018 (Riskesdas, 2018). Provinsi Riau menjadi urutan ke 17 dari 34 mengalami ganguan mental emosional, dan prevalensi ini naik dibandingkan tahun 2013, yakni 6\% menjadi 9,8\% pada usia 15 tahun ke atas (Riskesdas, 2018).

Kecemasan pada mahasiswa salah satu penyebabnya adalah ketika menghadapi ujian (Budi, 2017). Ujian memiliki peranan penting dalam menilai sejauh mana mahasiswa memahami materi yang telah disampaikan. Ujian juga merupakan nilai yang didapatkan secara keseluruhan (Basuki \& Hariyanto, 2015). Ujian menjadi sumber kecemasan bagi mahasiswa, salah satunya adalah ujian skill laboratoriy (Suryanto \& Isrovianingrum, 2018).

Skill laboratoriy merupakan tempat peserta didik mempergunakan pendekatan pemecahan masalah, dimana mahasiswa diajarkan keterampilan klinik yang bertujuan menunjang pencapaian kompetensi klinis (Nursalam \& Efendi, 2008). Nurini (2002) dalam Susanti (2010) menjelaskan bahwa skill laboratory merupakan fasilitas dimana tempat mahasiswa dapat berlatih keterampilanketerampilan medik yang mereka perlukan yang dibuat seperti antara perawat-klien, dan 
Erfiza Resti Rusdi, Yesi Hasneli, Sri Wahyuni, Efektivitas Terapi Murottal Al-Qur'an Terhadap Tingkat Kecemasan Mahasiswa Sebelum Ujian Skill Laboratory

kemudian dilakukan performance (penilaian kinerja) berdasarkan kemampuan peserta didik.

Performance (penilaian kinerja) yang dilakukan dalam skill laboratory bertujuan untuk mengetahui kemampuan mahasiswa dalam berbagai macam keterampilan keperawatan yang sesuai dengan situasi dan kondisi klien yang akan dijumpai dalam dunia kerja, sehingga nantinya mahasiswa benarbenar siap dalam menghadapi klien (Susanti, 2010). Performance (penilaian kinerja) yang dilakukan dalam skill laboratory sering sekali menyebabkan kecemasan terhadap mahasiswa, karena dalam ujian skill laboratory yang dibutuhkan adalah skill dan keahlian mahasiswa, sehingga berdampak pada kecemasan (Budi, 2017).

Suryanto dan Isrovianingrum (2018) menyatakan bahwa mahasiswa mengalami kecemasan dalam menghadapi ujian skill laboratorium baik sebelum ujian maupun pada waktu menjalani ujian. Yang, Chung dan Chang, (2014) menyatakan bahwa kecemasan mahasiswa dalam menghadapi ujian skill laboratory disebabkan oleh beberapa faktor yaitu sikap pengawas ujian, suasana (situasi) ujian, waktu uji yang singkat, keterampilan mahasiswa, ujian itu sendiri dan perasaan internal yang dialami oleh mahasiswa (tidak yakin lulus).

Perasaan cemas dapat mempersulit seseorang karena berdampak pada respon fisiologis yang dapat mempengaruhi kapasitas seseorang, sehingga dapat mempengaruhi tingkat kepercayaan diri (Direja, 2011). Kepercayaan diri yang dipengaruhi oleh kecemasan dapat menimbulkan gangguan kognitif, afektif maupun psikomotor, sehingga dapat membuat seseorang tidak dapat fokus dan berkonsentrasi dengan baik (Kusumawati \& Hartono, 2011). Berdasarkan hasil penelitian Untari (2014) mahasiswa yang mengalami kecemasan pada saat akan menghadapi ujian atau tes, berpengaruh pada hasil akhir nilai ujian/tesnya.

Penanganan kecemasan sangat penting untuk mendapatkan hasil ujian yang lebih baik (Suryanto \& Isrovianingrum, 2018). Beberapa terapi non farmakologi disebutkan dapat menurunkan kecemasan, salah satu diantaranya adalah dengan menggunakan audio terapi murottal Al-Qur'an (Risnawati, 2017).

Murottal merupakan bacaan ayat suci AlQur'an yang dibacakan oleh seorang qori' (pembaca Al-Quar'an) (Ahsin, 2008). AlQur'an merupakan obat yang paling komplit untuk segala jenis penyakit, baik penyakit fisik maupun psikologi, baik penyakit dunia maupun penyakit akhirat (Pedak, 2009). Salah satu penelitian menunjukkan, dengan murottal Al-Qur'an yang didengarkan dalam tempo lambat) dapat meningkatkan perasaan rileks (Faradisi \& Aktifah, 2018). Murottal AlQur'an dengan tempo $<60$ ketukan/menit dapat menurunkan hormon-hormon stress (epineprin, norepineprin, cortisol), dan 
mengaktifkan hormon endorphin, sehingga meningkatkan perasaan rileks, mengalihkan perhatian dari rasa takut, cemas, tegang, memperbaiki sistem kimia tubuh sehingga menurunkan tekanan darah, memperlambat pernapasan, detak jantung, denyut nadi, aktifitas gelombang otak, dan mempercepat penyembuhan (Heru, 2008).

Syafei dan Suryadi (2018) menyatakan salah satu surah Al-Qur'an yang memiliki efek terapeutik adalah surah Ar-Rahman yang terdiri atas 78 ayat, yang memiliki makna mengenai sifat pemurah dan sifat kasih sayang Allah SWT kepada hamba-Nya. Risnawati (2017) dalam penelitiannya mendapatkan bahwa mendengarkan murottal Al-Qur'an surah Ar-Rahman efektif terhadap penurunan tingkat kecemasan pada mahasiswa keperawatan semester VII UIN Alauddin Makasar.

Studi pendahuluan dalam bentuk wawancara yang dilakukan peneliti pada Maret 2019 terhadap mahasiswa angkatan 2018 di Fakultas Keperawatan Universitas Riau didapatkan bahwa kecemasan lebih sering dirasakan pada saat menghadapi ujian skill laboratory. Hal ini disebabkan ujian tersebut dipraktekkan dan diobservasi secara langsung oleh dosen, beda hal nya dengan ujian tulis yang hanya diobservasi tanpa dipraktekkan. Berdasarkan pengukuran tingkat kecemasan menggunakan kuesioner S-AI from $Y-1$ terhadap mahasiswa angkatan 2018 tersebut sebelum menghadapi ujian skill laboratory didapatkankan bahwa tingkat kecemasan terbanyak adalah kecemasan sedang-berat. Berdasarkan penjelasan diatas peneliti tertarik untuk melakukan penelitian tentang efektifitas terapi murottal Al-Qur'an terhadap tingkat kecemasan mahasiswa sebelum ujian skill laboratory.

\section{METODE PENELITIAN}

Penelitian ini menggunakan desain quasy experiment dengan kelompok eksperimen dan kontrol dengan dilakukan pretest dan post-test. Populasi dalam penelitian ini adalah mahasiswa program A angkatan 2018 di Fakultas Keperawatan Universitas Riau. Pengambilan sampel dengan simple random sampling yang menggunakan teknik undian (lottery technique) didapatkan 68 responden yang dibagi menjadi 34 kelompok eksperimen dan 34 kelompok kontrol. Waktu yang digunakan peneliti untuk penelitian ini dilaksanakan sejak tanggal dikeluarkan ijin penelitian dalam kurun waktu kurang lebih 2 bulan mulai dari pengumpulan data sampai pengolahan data yang meliputi penyajian dalam bentuk skripsi dan proses bimbingan berlangsung.

Variabel independen pada penelitian ini adalah pemberian terapi murottal Al-Qur'an surah Ar-Rahman yang diperdengarkan selama 15 menit pada ruangan tertutup yang tenang dan nyaman dengan menggunakan smartphone yang sudah terhubung dengan speaker portable, dengan kekuatan suara 50-60 db yang diukur dengan decibel meter pada kelompok eksperimen. Variabel dependen 
Erfiza Resti Rusdi, Yesi Hasneli, Sri Wahyuni, Efektivitas Terapi Murottal Al-Qur'an Terhadap Tingkat Kecemasan Mahasiswa Sebelum Ujian Skill Laboratory

adalah tingkat kecemasan mahasiswa sebelum ujian skill laboratory pada kelompok eksperimen dan kelompok kontrol.

Pemberian terapi murottal Al-Qur'an pada kelompok eksperimen dilakukan satu jam sebelum ujian skill laboratory di tempat dan ruangan yang telah disediakan peneliti, sedangkan pada kelompok kontrol dilakukan pada waktu yang sama, namun lokasi yang berbeda.

Lembar kuesioner S-AI from $Y-1$ digunakan untuk mengukur tingkat kecemasan pre-test dan post-test yang terdiri atas 20 pertanyaan. Kuesioner S-AI from $Y-1$ merupakan kuesioner baku yang sudah teruji validitas dan reliabilitasnya dengan nilai validitas rentang $0,76-0,78$ dan reliabilitasnya 0,93, no uji etik 032/EP-FKIK-UMY/II/2016.

Analisis data menggunakan analisis univariat dan bivariat. Analisis statitistik menggunkan uji beda dua mean dependent sample t-test dan independent t-test. Derajat kemaknaan $(\alpha)$ yang digunakan dalam penelitian ini adalah 0,05 .

\section{HASIL PENELITIAN}

\section{A. Analisis Univariat}

\section{Karakteristik responden}

Analisis univariat berdasarkan karakteristik responden dapat dijelaskan pada tabel dibawah ini.
Tabel 1

Distribusi karakteristik responden dan uji homogenitas

\begin{tabular}{|c|c|c|c|}
\hline $\begin{array}{c}\text { Karakteristik } \\
\text { Responden }\end{array}$ & $\frac{\text { Jumlah }}{\mathrm{N}}$ & $\begin{array}{c}\text { Persentase } \\
\%\end{array}$ & $\begin{array}{c}p \\
\text { value }\end{array}$ \\
\hline Usia & & & \\
\hline $\begin{array}{l}18 \text { tahun } \\
19 \text { tahun }\end{array}$ & $\begin{array}{l}37 \\
31 \\
\end{array}$ & $\begin{array}{l}54,4 \\
45,6 \\
\end{array}$ & 0,650 \\
\hline $\begin{array}{l}\text { Jenis Kelamin } \\
\text { Perempuan } \\
\text { Laki-laki }\end{array}$ & $\begin{array}{c}66 \\
2\end{array}$ & $\begin{array}{c}97,1 \\
2,9\end{array}$ & 1,000 \\
\hline
\end{tabular}

Tabel 1 menunjukkan distribusi responden menurut umur terbanyak adalah 18 tahun sebanyak 37 responden $(54,4 \%)$, sedangkan menurut jenis kelamin terbanyak adalah perempuan sebanyak 66 responden (97,1\%). Hasil uji Levene Test untuk semua karakteristik responden adalah homogen dengan $p$ value $>0,05$.

Karakteristik tingkat kecemasan berdasarkan usia dapat dijelaskan pada tabel 2 berikut:

Tabel 2

Distribusi karakteristik tingkat kecemasan berdasarkan usia

\begin{tabular}{lcccc}
\hline \multicolumn{1}{c}{ Usia } & \multicolumn{3}{c}{ Tingkat Kecemasan } & Total \\
\hline & Ringan & Sedang & Berat & \\
\hline 18 tahun & 0 & 15 & 22 & 37 \\
19 tahun & 0 & 23 & 8 & 31 \\
\hline Total & & & & 68 \\
\hline
\end{tabular}

Tabel 2 menunjukkan bahwa usia 18 tahun mengalami tingkat kecemasan lebih tinggi dibandingkan usia 19 tahun, dimana tingkat kecemasan usia 18 tahun terbanyak pada kecemasan berat sebanyak 22 responden, sedangkan tingkat kecemasan usia 19 tahun terbanyak pada kecemasan sedang sebanyak 23 orang. 
Karakteristik tingkat kecemasan berdasarkan jenis kelamin dapat dijelaskan pada tabel 3 berikut:

Tabel 3

Distribusi karakteristik tingkat kecemasan berdasarkan jenis kelamin

\begin{tabular}{ccccc}
\hline $\begin{array}{c}\text { Jenis } \\
\text { Kelamin }\end{array}$ & \multicolumn{3}{c}{ Tingkat Kecemasan } & Total \\
\hline & Ringan & Sedang & Berat \\
\hline Perempuan & 0 & 36 & 30 & 66 \\
Laki-laki & 0 & 2 & & 2 \\
\hline \multicolumn{1}{c}{ Total } & & & & 68 \\
\hline
\end{tabular}

Tabel 3 menunjukkan bahwa perempuan mengalami tingkat kecemasan lebih tinggi dibandingkan laki-laki, dimana perempuan mengalami tingkat kecemasan derajat sedangberat, sedangkan laki-laki mengalami tingkat kecemasan derajat sedang.

\section{Rata-rata Distribusi Tingkat \\ Kecemasan pretest dan posttest Kelompok Eksperimen dan Kelompok \\ Kontrol}

Rata-rata distribusi tingkat kecemasan pada responden dapat dijelaskan pada tabel 4 berikut:

Tabel 4

Rata-rata tingkat kecemasan pada kelompok eksperimen dan kelompok kontrol

\begin{tabular}{lcccc}
\hline \multicolumn{1}{c}{ Variabel } & Mean & SD & Min & Max \\
\hline $\begin{array}{l}\text { Kelompok } \\
\text { eksperimen }\end{array}$ & & & & \\
$\begin{array}{l}\text { Pre test } \\
\text { Post test }\end{array}$ & 60,35 & 7,232 & 44 & 73 \\
\hline $\begin{array}{l}\text { Kelompok } \\
\text { control }\end{array}$ & & & & \\
Pre test & 54,06 & 10,404 & 40 & 73 \\
Post test & 54,56 & 9,952 & 40 & 73 \\
\hline
\end{tabular}

Tabel 4 menunjukkan bahwa pada kelompok eksperimen didapatkan rata-rata tingkat kecemasan pre test yaitu 60,35 dan rata-rata tingkat kecemasan post test yaitu 36,41, sedangkan pada kelompok kontrol didapatkan rata-rata tingkat kecemasan pre test yaitu 54,06 dan rata-rata post test yaitu 54,56.

\section{B. Analisis Bivariat}

Analisis bivariat digunakan untuk menilai perbedaan tingkat kecemasan responden pada kelompok eksperimen dan kontrol. Proses pengolahan data dilakukan setelah dilakukan uji normalitas data.

Tabel 5

Uji normalitas data tingkat kecemasan pre test dan post test pada kelompok eksperimen dan kelompok kontrol

\begin{tabular}{llc}
\hline \multicolumn{1}{c}{ Variabel } & N & p value \\
\hline $\begin{array}{l}\text { Kelompok } \\
\text { eksperimen }\end{array}$ & & \\
$\begin{array}{l}\text { Pre test } \\
\text { Post test }\end{array}$ & 34 & 0,126 \\
\hline Kelompok & 34 & 0,172 \\
control & & \\
Pre test & & \\
Post test & 34 & 0,200 \\
\hline
\end{tabular}

Tabel 5 menunjukkan uji normalitas data menggunakan uji Kolmogorov-Smirnov didapatkan hasil pre test dan post test $p$ value pada kelompok eksperimen $>\alpha(0,05)$, sedangkan pre test dan post test $p$ value pada kelompok kontrol $>\alpha(0,05)$, maka disimpulkan bahwa kedua kelompok data terdistribusi normal, sehingga memenuhi syarat uji parametrik dependent sample t-test dan independent sample t-test.

1. Perbedaan Tingkat kecemasan Pretest dan Posttest pada Kelompok Eksperimen yang Diberi Terapi Murottal Al-Qur'an dan Kelompok Kontrol yang Tidak Diberi Terapi Murottal Al-Qur'an

Tabel 6

Perbedaan tingkat kecemasan pretest dan posttest pada kelompok eksperimen yang 
Erfiza Resti Rusdi, Yesi Hasneli, Sri Wahyuni, Efektivitas Terapi Murottal Al-Qur'an Terhadap Tingkat Kecemasan Mahasiswa Sebelum Ujian Skill Laboratory

diberi terapi murottal al-qur'an dan kelompok kontrol yang tidak diberi terapi murottal AlQur'an

\begin{tabular}{lcccc}
\hline \multicolumn{1}{c}{ Variabel } & Mean & Mean & SD & $\begin{array}{c}\boldsymbol{p} \\
\text { value }\end{array}$ \\
\hline $\begin{array}{l}\text { Kelompok } \\
\text { eksperimen }\end{array}$ & & & & \\
$\begin{array}{l}\text { Pre test } \\
\text { Post test }\end{array}$ & 60,35 & 23,94 & 7,232 & 0,000 \\
\hline $\begin{array}{l}\text { Kelompok } \\
\text { control }\end{array}$ & & & 6,382 & \\
$\begin{array}{l}\text { Pre test } \\
\text { Post test }\end{array}$ & 54,06 & $-0,500$ & 10,404 & 0,243 \\
\hline
\end{tabular}

Tabel 6 menunjukkan bahwa kelompok eksperimen memiliki perbedaan yang bermakna pada penurunan tingkat kecemasan pre test dan post test dengan hasil yang signifikan yaitu $p$ value $0,000<\alpha(0,05)$, sedangkan pada kelompok kontrol tidak memiliki perbedaan yang bermakna pada penurunan tingkat kecemasan pre test dan post test dengan hasil $p$ value $0,243>\alpha(0,05)$.

\section{Perbedaan Tingkat Kecemasan Posttest} pada Kelompok Eksperimen yang Diberi Terapi Murottal Al-Qur'an dan Kelompok Kontrol yang Tidak Diberi

\section{Terapi Murottal Al-Qur'an}

Tabel 7

Perbedaan tingkat kecemasan posttest pada kelompok eksperimen yang diberi terapi murottal al-qur'an dan kelompok kontrol yang tidak diberi terapi murottal Al-Qur'an

\begin{tabular}{|c|c|c|c|c|}
\hline Variabel & Mean & $\begin{array}{c}\text { Mean } \\
\text { perbedaan }\end{array}$ & SD & $\begin{array}{c}p \\
\text { value }\end{array}$ \\
\hline $\begin{array}{l}\text { kelompok } \\
\text { eksperimen } \\
\text { Posttest }\end{array}$ & 36,41 & \multirow[b]{2}{*}{$-18,147$} & 6,382 & \multirow[b]{2}{*}{0,000} \\
\hline $\begin{array}{l}\text { kelompok } \\
\text { control } \\
\text { Posttest }\end{array}$ & 54,56 & & 9,952 & \\
\hline
\end{tabular}

Tabel 7 menunjukkan tingkat kecemasan post test pada kelompok eksperimen dan kelompok kontrol didapatkan perbedaan yang signifikan yaitu $p$ value $0,000<\alpha(0,05)$. Hal ini menunjukkan bahwa hipotesi nol (Ho) ditolak, disimpulkan bahwa terapi murottal AlQur'an efektif terhadap penurunan tingkat kecemasan mahasiswa sebelum mengikuti ujian skill laboratory.

\section{PEMBAHASAN}

\section{A. Analisis Univariat}

\section{Karakteristik responden}

\section{a. Usia}

Berdasarkan hasil penelitian ini didapatkan bahwa usia responden terbagi dua yaitu usia 18 tahun dan usia 19 tahun. Usia terbanyak dalam penelitian ini adalah usia 18 tahun sebanyak 37 orang $(54,4 \%)$. Hal tersebut sejalan dengan pendapat Ramainah (2010) menyatakan bahwa kriteria diagnostik seseorang mengalami gangguan kecemasan pada umumnya adalah 18 tahun.

Hasil penelitian ini juga didapatkan bahwa usia 18 tahun mengalami tingkat kecemasan lebih tinggi dibandingkan usia 19 tahun. Hal tersebut sesuai dengan penelitian Husianna, Surawijaya dan Maulana (2014) yang menyatakan bahwa mahasiswa tingkat pertama yang mengalami kecemasan paling tinggi berada pada usia 18 tahun. Menurut Potter dan Perry (2012) umur dapat berpengaruh tehadap maturasi, dan tingkat maturasi mempengaruhi tingkat kecemasan. Hal ini dikarenakan umur berkaitan erat dengan tingkat maturasi (kematangan). 


\section{b. Jenis Kelamin}

Hasil penelitian ini didapatkan bahwa mahasiswa mengalami kecemasan sebelum ujian skill laboratory terbanyak di Fakultas Keperawatan Universitas Riau angkatan 2018 adalah berjenis kelamin perempuan sebanyak 63 orang (92\%). Penelitian ini didukung oleh Suryanto dan Isrovianingrum (2018) bahwa dari 89 responden jenis kelamin perempuan mendominasi sampel yaitu sebanyak 80 orang $(89,9 \%)$. Hal tersebut sesuai dengan penelitian Yuhelrida, Andriani dan Sofya (2016) yang menemukan bahwa jenis kelamin perempuan lebih banyak dibandingkan laki-laki pada mahasiswa keperawatan.

Penelitian ini juga mendapatkan hasil bahwa tingkat kecemasan perempuan lebih tinggi dibandingkan laki-laki. Hal tersebut sejalan dengan pendapat Rooney (2012) yang menyatakan bahwa mahasiswa berjenis kelamin perempuan mengalami tingkat kecemasan lebih tinggi dibandingkan laki-laki, karena perempuan rentan mengalami perubahan emosional, perbedaan hormonal, rendahnya tingkat percaya diri dan tingginya harapan terhadap sesuatu. Menurut Kaplan dan Saddock (2012) perempuan lebih peka terhadap emosinya dibandingkan laki-laki, sehingga hal tersebut berpengaruh terhadap perasaan cemasnya.

\section{B. Analisis Bivariat}

1. Perbedaan Tingkat Kecemasan Posttest pada Kelompok Eksperimen yang Diberi Terapi Murottal Al-Qur'an dan
Kelompok Kontrol yang Tidak Diberi

\section{Terapi Murottal Al-Qur'an}

Uji dependen t-test didapatkan mean tingkat kecemasan responden sebelum diberikan intervensi yaitu 60,35, dengan selisih 23,94 dari hasil setelah diberikan intervensi mean 36,41. Hasil analisa data diperoleh $p$ value $0,000<\alpha(0,05)$, dapat disimpulkan ada penurunan mean tingkat kecemasan yang signifikan pada kelompok eksperimen. Penurunan tingkat kecemasan pada kelompok eksperimen ini terjadi karena adanya pemberian intervensi berupa murotal Al-Qur'an.

Mendengarkan murottal Al-Qur'an memiliki dampak yang luar biasa terhadap kesehatan. Heru (2008) menyatakan bahwa terapi murottal Al-Qur'an dengan tempo yang lambat (<60 ketukan/menit) memberikan efek relaksasi yang akan menghambat hormon yang dapat meningkatkan kecemasan, dengan cara menekan kortisol atau menekan hormonhormon stress, mengaktifkan hormon endorphin yang berfungsi meningkatkan perasaan rileks, mengurangi stress, mengurangi ketegangan dalam tubuh serta mempengaruhi kerja kardiovaskuler, memperbaiki sistem kimia tubuh dan memperbaiki metabolisme tubuh.

Murottal Al-Qur'an mempunyai harmonisasi yang indah, sehingga ketika diperdengarkan harmonisasi akan masuk ke dalam telinga, menggetarkan gelombang telinga, mengguncangkan cairan ditelinga dalam, serta menggetarkan sel-sel rambut 
Erfiza Resti Rusdi, Yesi Hasneli, Sri Wahyuni, Efektivitas Terapi Murottal Al-Qur'an Terhadap Tingkat Kecemasan Mahasiswa Sebelum Ujian Skill Laboratory

didalam koklea dan selanjutnya melalui saraf koklearis menuju otak, sehingga menciptakan imajinasi keindahan di otak kiri dan otak kanan, yang akan memberikan dampak berupa kenyamanan dan ketenangan bagi pendengarnya (Pedak, 2009). Kenyamanan dan ketenangan mendengar murottal AlQur'an dirasakan karena di otak terdapat sistem limbik yang mengatur terhadap respon emosi. Sistem limbik tersebut didalamnya terdapat neurotransmiter yang mengatur mengenai stress, ansietas dan beberapa gangguan terhadap ansietas (Ibrahim, 2012).

Murottal Al-Qur'an yang digunakan dalam penelitian ini adalah murottal Al-Qur'an surah Ar-Rahman. Surah Ar-Rahman dipilih sebagai ayat dalam terapi murottal Al-Qur'an karena surah Ar-Rahman memiliki arti "maha pemurah, maha cinta, maha sayang" yang mengingatkan manusia agar berfikir tentang segala nikmat yang telah diberikan Allah kepada manusia (Ahsin, 2008). Selain itu surah Ar-Rahman tergolong kedalam surah makiyah yang tidak terlalu panjang dan terdapat 30 ayat diantaranya pengulangan kalimat yang sama sehingga membuat pendengarnya lebih fokus terhadap murottal yang didengarkan.

Pemberian intervensi murottal AlQur'an surah Ar-Rahman dalam penelitian ini diperdengarkan kepada responden selama 15 menit. Menurut Potter dan Perry (2009) mengatakan bahwa waktu yang dibutuhkan untuk terapi supaya dapat memberikan efek teraupetik adalah minimal 10 menit.

\section{Perbandingan Tingkat Kecemasan Postest pada Kelompok Eksperimen yang Diberikan Terapi Murottal Al- Qur'an dan Posttest pada kelompok Kontrol yang Tidak Diberikan Terapi Murottal Al-Qur'an}

Hasil uji independet t-test didapatkan hasil mean post test kelompok eksperimen adalah 36,41 dengan standar deviasi 6,382 dan pada kelompok kontrol nilai mean post test adalah 54,56 dengan standar deviasi 9,952, sedangkan mean perbedaan post test kelompok eksperimen dan kelompok kontrol adalah 18,147. Hasil uji statistik diperoleh $p$ value $0,000<\alpha(0,05)$, maka dapat disimpulkan ada perbedaan tingkat kecemasan antara kelompok eksperimen yang diberikan terapi murottal AlQur'an dengan kelompok kontrol yang tidak diberikan terapi murottal Al-Qur'an. Dapat disimpulkan bahwa $\mathrm{H}_{0}$ ditolak yang artinya terapi murottal Al-Qur'an efektif terhadap penurunan tingkat kecemasan mahasiswa sebelum ujian skill laboratory di Fakultas keperawatan Universitas Riau.

Adanya perbedaan yang signifikan atau bermakna tingkat kecemasan pada kelompok eksperimen disebabkan oleh adanya motivasi diri responden untuk mengikuti terapi murottal Al-Qur'an yang diberikan, mengikuti prosedur terapi dengan baik, dan adanya motivasi dari diri responden untuk menurunkan tingkat kecemasannya. Selain itu kelompok 
eksperimen sangat antusias dalam mendengarkan murottal Al-Qur'an.

Responden pada kelompok eksperimen maupun kelompok kontrol sangat kooperatif dalam menjalankan penelitian karena hal tersebut didukung oleh rasa ingin tahu yang kuat terhadap skor kecemasan serta penanganan non farmakologis yang dapat dilakukan terhadap kecemasan yang dirasakan pada saat menghadapi ujian skill laboratory, sehingga menjadi informasi dalam menambah pengetahuan.

\section{SIMPULAN}

Penelitian ini didapatkan hasil bahwa mayoritas umur mahasiswa tingkat pertama angkatan 2018 di Fakultas Keperawatan Universitas Riau adalah 18 dan 19 tahun. Usia terbanyak dan mengalami kecemasan tertinggi adalah 18 tahun dengan nilai 54,4\%. Jenis kelamin terbanyak dan mengalami tingkat kecemasan tertinggi adalah perempuan berjumlah 97,1\%. Hasil analisa statistik didapatkan bahwa terapi terapi murottal AlQur'an Efektif terhadap penurunan tingkat kecemasan mahasiswa sebelum ujian skill laboratory di Fakultas Keperawatan Universitas Riau dengan $p$ value $0,000<\alpha$ $(0,05)$.

\section{SARAN}

Terapi murottal Al-qur'an merupakan terapi non farmakologi yang efektif dalam menurunkan tingkat kecemasan, sehingga dapat menambah informasi bagi mahasiswa terkait terapi yang dapat menurunkan kecemasan dan menjadi salah satu terapi pilihan dalam mengatasi kecemasan, terutama pada mahasiswa dalam menghadapi ujian skill laboratory. Menambah informasi serta rujukan bagi peneliti selanjutnya untuk mengembangkan lagi surah dalam Al-Quran yang dapat dijadikan sebagai terapi menurunkan tingkat kecemasan mahasiswa sebelum ujian skill laboratory.

\section{DAFTAR PUSTAKA}

Ahsin. (2008). Kamus ilmu Al-Qur'an. Jakarta: Amzah

Basuki, I., \& Hariyanto. (2015). Assesmen pembelajaran. Bandung: Remaja Rosdakarya Offset

Budi, Y, S. (2017). Faktor-Faktor yang Mempengaruhi Kecemasan Mahasiswa Studi d III Keperawatan Dalam menghadapi Ujian Skill Laboratorium: Studi mixed Methods di STIKES Bayuwangi. Tesis. UMY

Direja, A. H. S. (2011). Buku ajar asuhan keperawatan jiwa. Yogyakarta: Nuha Medika

Faradisi, F. \& Akhtifah, N. (2018). Pengaruh Pemberian Terapi Murottal Al-Qur'an Terhadap Penurunan Kecemasan Post Operasi. Profesi Islam: Media Publikasi Penelitian. 15 (2). 6

Hawari, D. (2011). Manejemen stress cemas dan depresi. Jakarta: FKUI

Heru. (2008). Ruqyah Syar'I berlandasan kearifan lokal. Jakarta: FKUI

Husianna, S. T., Surawijaya, A. K., \& Maulana, T. A. (2014). Gambaran Tingkat Kecemasan Pada Mahasiswa Semester 1 Di Fakultas Kedokteran. Skripsi. Universitas Kristen Maranatha

Ibrahim, A. S. (2012). Panik neurosis dan gangguan cemas. Tangerang: Jelajah Nusa.

Kaplan, H. I, \& Saddock, B. J. (2012). Sinopsis psikiatrik, 8 th ed. Jakarta: Bina Rupa Aksara 
Kusumawati, F., \& Hartono, Y. (2011). Buku ajar keperawatan jiwa. Jakarta: Salemba Medika

Nursalam., \& Efendi, F. (2008). Pendidikan dalam keperawatan. Jakarta: Selemba Medika

Pedak, M. (2009). Mukjizat terapi Qur'an untuk hidup sukses. Jakarta: Wahyumedia

Potter, P., \& Perry, A., (2009). Fundamentals of nursing edisi 7. Jakarta: Selemba Medika

Potter, P., \& Perry, A., (2012). Fundamentals of nursing edisi 8. Jakarta: Selemba Medika

Ramainah. (2010). Kecemasan: Bagaimana mengatasi penyebabnya. Jakarta: Pustaka Obor

Riset Kesehatan Dasar (Riskesdas). (2018). Badan Penelitian dan Pengenbangan Kesehatan Kementrian RI tahun 2018. Diakses: 12 Desember 2018 dari www.depkes.go.id

Risnawati. (2017). Efektifitas Terapi Murottal Al-Qur'an dan Terapi Musik Terhadap Tingkat Kecemasan Mahasiswa Keperawatan Semester VIII Alauddin Makasar. Skripsi. Makasar: Universitas Islam Negeri Makasar

Rooney, D. M. (2012). Medical Students Anxiety Toward The Male Genitourinery Rectal Ezamination. Universiti Of Illinois Journal, 1-9

Suryanto., \& Isrovianingrum, R. (2018). Kecemasan Mahasiswa Perawat Sebelum Ujian Keterampilan Di
Laboratorium. Jurnal of Health Sciences, Vol. 11, no. 2, 97-103.

Susanti. (2010). Implementasi Pembelajaran Skill laboratory (Study Kasus di program Studi D III Keperawatan Sekolah Tinggi Ilmu kesehatan An-Nur Purwodadi). Tesis. Surakarta: Universitas Sebelas Maret

Syafei, A., \& Suryadi, Y. (2018). Pengaruh Pemberian Terapi Audio Murottal Qur'an Surat Ar-Rahman terhadap Tingkat Kecemasan pada Pasien PreOperasi Katarak Senilis. Jurnal Kesehatan, 9(1), 126-130.

Untari, I. (2014). Hubungan Antara Kecemasan Dengan Prestasi Ujian Pada Mahasiswa Akper PKU Muhammadiyah Surakarta. Jurnal kebidanan, Vol. VI, no. 1, 10-16.

World Health Organization. (2018). Mental Dissorders Fact Sheets. World Health Organization.http://www.who.int/medi acentre/factsheets/fs396/en. Diakses: 21 Desember 2018

Yang, R., Lu, Y., Chung, M., \& Chang, S. (2014). Depeloving a short version of the axiety scale for baccalaureate nursing skills test- A preliminary study. Nurse Education in practice, Vol. 14, no. 6, 586-590.

Yuhelrida., Andriani, P., \& Sofya, P. A. (2016). Tingkat Kecemasan Dalam Menghadapi Ujian Skill Laboratorium (Studi pada Peserta UKMP2DG Unsyiah Periode II Tahun 2016). Journal Caninus Dentistry, Vol. 1, no. 4, 26-31. 